\title{
Extensive vertebrate tracksite from the Upper Red Formation (middle-late Miocene), west Zanjan, northwestern Iran
}

\author{
Nasrollah Abbassi ${ }^{1}$, Masoumeh Khoshyar ${ }^{1}$, Spencer G. Lucas ${ }^{2}$, and Farid Esmaeili ${ }^{3}$ \\ ${ }^{1}$ Department of Geology, Faculty of Science, University of Zanjan, Zanjan, 45371-38791, Iran \\ ${ }^{2}$ New Mexico Museum of Natural History and Science, 1801 Mountain Road N.W., Albuquerque, NM 87104-1375, USA \\ ${ }^{3}$ Department of Surveying Engineering, Faculty of Technology and Engineering, Zanjan Branch, \\ Islamic Azad University, Zanjan, 45156-58145, Iran
}

Correspondence: Nasrollah Abbassi (abbasi@znu.ac.ir)

Received: 3 March 2021 - Revised: 17 March 2021 - Accepted: 18 March 2021 - Published: 23 April 2021

\begin{abstract}
An extensive vertebrate tracksite from the middlelate Miocene Upper Red Formation in western Zanjan Province, northwestern Iran, provides new records of paleobiogeographical significance. These are records of common footprints of felids referred to as Felipeda lynxi Panin and Avram, canids referred to as Canipeda longigriffa Panin and Avram and less common bird footprints referred to as Iranipeda abeli Lambrecht. The Canipeda record establishes the late Miocene presence of canids on the Iranian Plateau as part of the Eurasia-wide "Eucyon event". The Felipeda footprints are consistent with body fossil and footprint records elsewhere in Eurasia that indicate a widespread distribution of felids by late Miocene time. An unusual trace associated with the footprints is a large, shallow grazing or locomotion trace similar to Megaplanolites in some features but distinctive in various features and its occurrence in nonmarine facies, and it will be the subject of further study.
\end{abstract}

\section{Introduction}

The Upper Red Formation (URF) is known as the main and most extensive Miocene rock unit in Central Iran. The Lower Red Formation (LRF) and URF are the two main continental rock units, composed of marl, sandstone and gypsum red beds, that form the lower and upper boundaries, respectively, of the marine sediments of the Oligo-Miocene Qom Formation. All of these formations were deposited during the Oligocene to late Miocene after the late Eocene Pyrenean orogeny in the Central Iran basin. Both the LRF and URF are poor in index fossils, and their ages have been estimated by their lithostratigraphic position around the Qom Formation (Rupelian to Tortonian), so the LRF is considered early Oligocene in age, and the URF is assigned to the middle to late Miocene (Rahimzadeh, 1994; Gansser, 1955; Aghanabati, 2004). Continental facies of the URF are a good candidate for vertebrate tracksite studies (Amini, 2001; Rafiei et al., 2011; Amini, 1997), and numerous vertebrate footprints have been reported from this formation (Abbassi, 2010; Abbassi and Amini, 2008; Abbassi and Shakeri, 2005). Vertebrate footprints of the URF, however, are very diverse and abundant in its outcrops in northwestern Iran, and new tracksites have also been discovered by one of us (Nasrollah Abbassi) during the last decade in Zanjan Province. The main aim of the present research is to report and introduce one of these tracksites, which includes an extensive assemblage of abundant and well-preserved mammal and bird footprints on a large cliff in the Chehrabad area in western Zanjan Province (Fig. 1). The location of this large slab $(12 \times 10 \mathrm{~m})$ is in the north Hamzalu village; GPS coordinates are $36^{\circ} 56.045^{\prime}$ latitude and $47^{\circ} 50.262^{\prime}$ longitude.

\section{Geology of the URF}

The type locality of the URF was designated in the Qom area, Central Iran, by geologists of the National Iranian Oil Company (NIOC, 1959). The URF conformably overlies the Qom Formation via the intercalation of evaporitic rocks and weathered sandstone layers. The URF is an upward coarsening sequence with alternations of marls, siltstones, sandstones and conglomerate, which are unconformably overlain by Pliocene sediments. The outcrops of the URF in the Great 


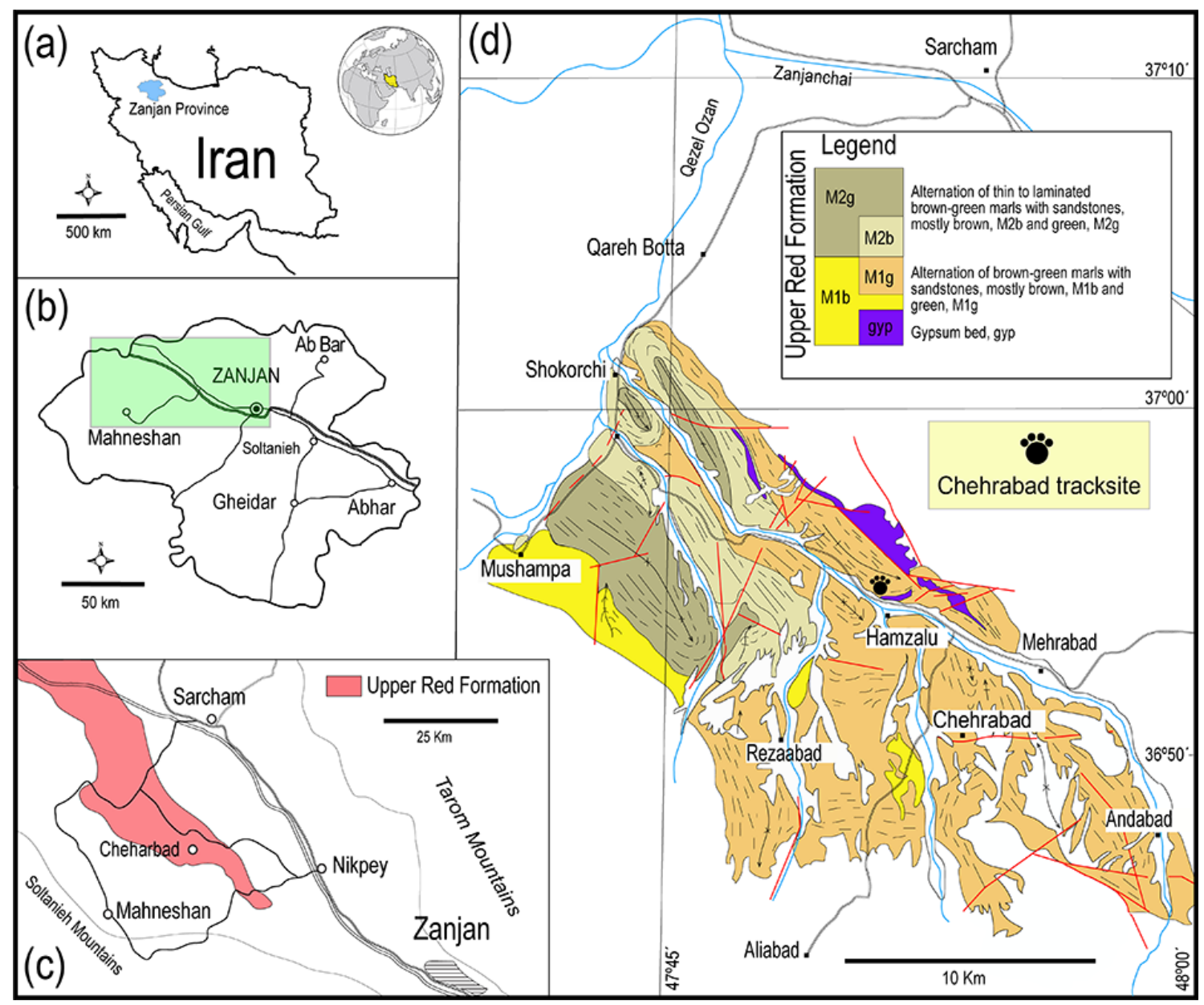

Figure 1. Location and geological map: (a) Location of Zanjan Province in Iran, (b) location of the study area in the west of Zanjan, (c) outcrop of Upper Red Formation (URF) in the Chehrabad area, and (d) geological map of the URF and location of studied tracksite. Base geological map by Lotfi (2001) (with permission).

Kavir area in north-central Iran show its maximum thickness ( $>6000 \mathrm{~m}$ ) with numerous evaporite diapiric structures. The thickness and rock facies of the URF decrease towards the northwest $(1000-2000 \mathrm{~m})$. Geologists of the NIOC divided the URF into two rock units in the Qom area as follows: M1 - lower evaporite subunit (300-400 m), composed of dark brown to red salt, anhydrite, pebbly terrigenous layers and thin shale beds, and M2 - upper subunit (3000-5000 m), which includes gypsiferous marls, brown to red sandstones, and alternations of light red marls with sandstones.

Additional data show that M1 is the uppermost member of the Qom Formation, and M2 is classifiable into three subunits in the Qom area as follows: m1- dark red gypsiferous sandstone, shale and siltstone with the green key bed in the lower part (2000 m thick), m2 - mainly eroded sandstone (about $1000 \mathrm{~m}$ thick), and $\mathrm{m} 3$ - pale yellow, strongly gypsiferous siltstone and marl with intercalations of soft calcareous sandstone (200-500 $\mathrm{m}$ thick) (Mostofi and Frei, 1959; Abaie et al., 1964).
The URF has very extensive outcrops in the southern and western parts of Zanjan Province. Stöcklin and EftekharNezhad (1969) divided the URF into two subunits in the southern parts of the province. The lower subunit (M1, 600$700 \mathrm{~m}$ thick) is characterized by its alternating beds that are characterized by colorfully banded white-green, white-pink, purple, violet and brown strata and by a relatively high content of evaporites. Colored marls with thin siltstone, sandstone, salt and gypsum beds and veins are the dominant rocks. There are gypsum beds, however, in a few diapiric structures in the lower part of the subunit. An andesitic crystal tuff (4 m thick) is also present in the lower subunit M1. The uniform, red-colored upper subunit (M2, 1500-2000 m thick) consists of clayey, marly and sandy shales with sandstone intercalations. Local to reginal conglomerate layers and lenses occur in this subunit. The gypsum layers are relatively less than in M1.

Outcrops of M1 in the western part of Zanjan Province around the Qezel Ozan River (1000-2000 m thick) include 


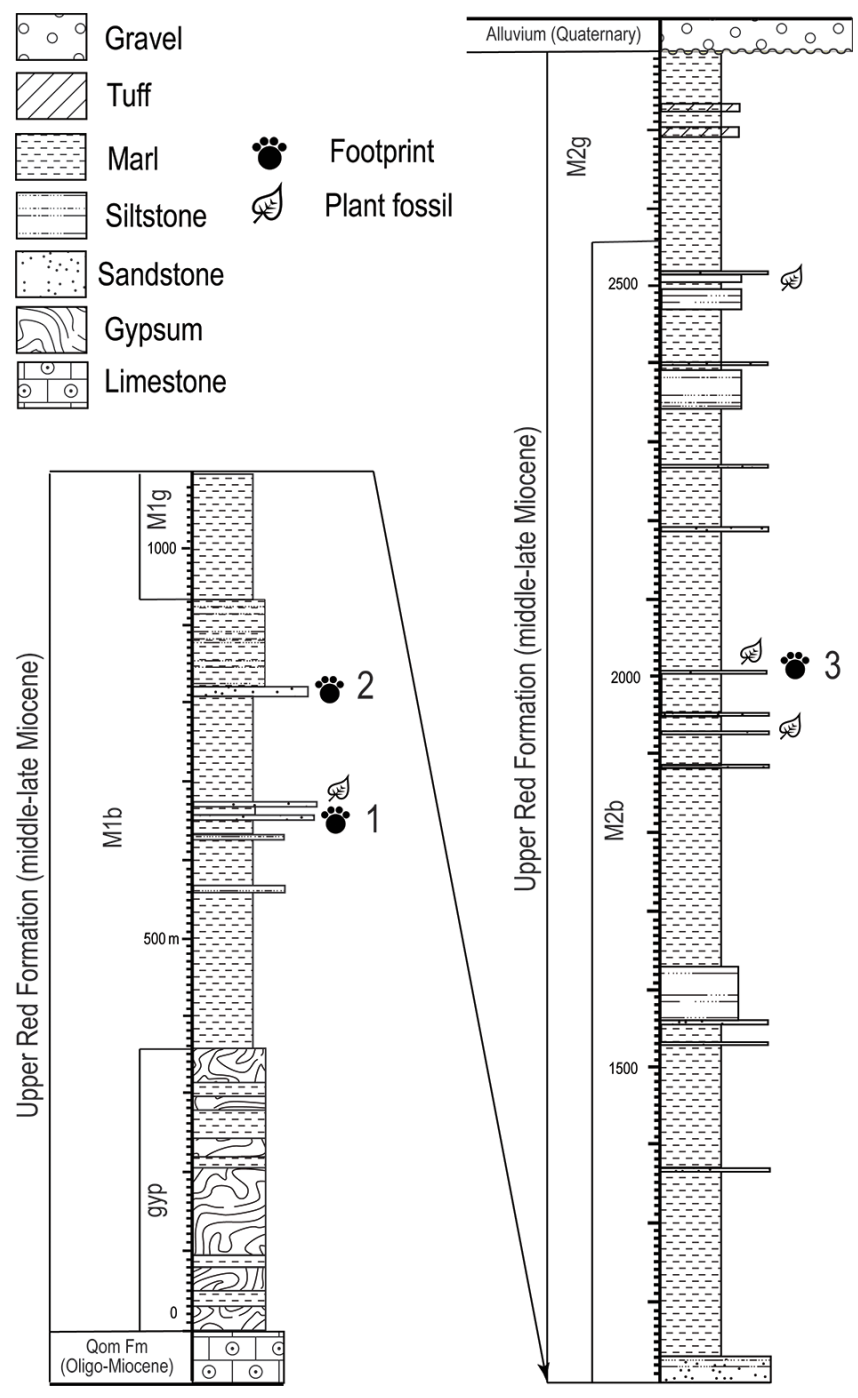

Figure 2. Stratigraphic column of URF in the west of Zanjan Province with three vertebrate footprints bearing lithohorizons. The Chehrabad tracksite is in the second lithohorizon.

light red- to brown-colored marls with a distinctive gypsum layer at the lower boundary with the Qom. Vertebrate footprints have been found in two horizons in this subunit in the study area in the upper most layers of M1, which are green marls. M2 consists of dark brown-green marls with sandstone layers. Only one vertebrate-footprint-bearing horizon has been identified in M2 in western Zanjan (Fig. 2).

The tracksite studied here is north of Hamzalu village, in the Chehrabad area, western Zanjan, in green and brown marls with sandstone and siltstone intercalations, and it belongs to the second footprint-bearing layer of M1 (Fig. 2). Vertebrate footprints were discovered in detrital layers preserved in convex hyporelief with non-biogenic structures that include mud cracks, flutes, grooves and prod casts.

No age diagnostic fossils have been found in the URF in the Zanjan area. The URF is generally dated as middle to late Miocene in age because it overlies the Qom Formation and is overlain by Pliocene conglomerate. The uppermost layer of the Qom Formation is dated as Burdigalian, ca. $17 \mathrm{Ma}$ (Schuster and Wielandt, 1999; Daneshian and Ramezani Dana, 2007). Magnetostratigraphic data show that the URF adjacent to the southern Alborz Mountains ranges in age between 17.5 and $7.5 \mathrm{Ma}$ (Ballato et al., 2008). To refine the chronology of the URF in the Qezel Ozan area in the west of Zanjan, Ballato et al. (2017) determined an ${ }^{40} \mathrm{Ar} /{ }^{39} \mathrm{Ar}$ age of $15.0 \pm 0.3$ to $25.0 \pm 1.3 \mathrm{Ma}$ and a zircon $\mathrm{U}-\mathrm{Pb}$ age of $10.7 \pm 0.2$ to $19.8 \pm 0.9 \mathrm{Ma}$.

This formation is poor in body fossils, and sparse Turritella sp. (gastropod), Dreissensia sp. (bivalve), plant debris and undetermined vertebrate fossils have been reported (Rahimzadeh, 1994).

The uppermost reefal limestone of the Qom Formation (Member $f$ ) is overlain by evaporite and terrigenous layers, and it is early Miocene (Burdigalian) in age (Daneshian and Ramezani Dana, 2007; Mohammadi, 2020; Okhravi, 1998; Reuter et al., 2009). Thus, gypsum beds in the study area are assignable to the Qom Formation; the URF begins with red marls in the study area with two lithostratigraphic units, M1 and M2. M1 was deposited on the f member of the Qom Formation, immediately above its evaporites. Thus, the lower parts of the URF basin began in the Burdigalian, and the zircon $\mathrm{U}-\mathrm{Pb}$ age of $10.7 \pm 0.2 \mathrm{Ma}$ is the youngest radiometric age date for the URF in western Zanjan (Ballato et al., 2017). Therefore, the continental basin of the URF on the southern flank of the Alborz Mountains in the Zanjan area was present during the late Burdigalian to early Tortonian. During this time interval (about 16-10 Ma), the prevailing climate of the URF basin has been estimated as warm and dry and affected by the surrounding topography such as the evolution of the Alborz Mountains (Ballato et al., 2010; Cronin, 2009).

The URF was deposited in continental environments by braided to meandering rivers, playa lakes and ephemeral ponds. Paleocurrent indicators show that sediments were transported from several points into the URF basin, particularly from the north and south (Amini, 1997). The fluvial depositional systems, including distal braided river, meandering river, and proximal braided river, were distinguished in the Avaj area, Hamadan Province, northwest Iran (Rafiei et al., 2011). The basin margins are delineated by a combination of active, strike-slip and normal fault systems (Alavi, 2004; Morley et al., 2009). These fault systems controlled the subsidence in small foredeep basins of the URF during the early-middle Miocene.

\section{Study method}

The footprint-bearing layer crops out as a large scarp cliff $(12 \times 10 \mathrm{~m})$, and only its lower part is accessible. This layer is coarse-grained, dark brown sandstone and includes numerous carnivore and bird tracks with very large burrows or 
trails, all of them preserved in convex hyporelief. A quadcopter unmanned aerial vehicle (UAV), model DJI Phantom 3 GL300C, was used to prepare photographs of all parts of the layer (Fig. 3).

This research has used the UAV photogrammetry method to produce an accurate 3D model and orthomosaic of the bedding surface. The wall convergent imaging, at four different height rings, was undertaken using a 12 megapixel Sony Exmor $1 / 2.3^{\prime \prime} 4 \mathrm{~K}$ camera mounted on the DJI Phantom 3 UAV. Five scale bars consisting of coded targets have been used to develop a real-scale 3D model. The 3D point clouds were extracted from the captured images using the structure from motion (SFM) method. Then, mesh and texture were built on a point cloud. In the developed close-range photogrammetry network, the average accuracy of estimating the terrestrial coordinates of points per check scale bars is $1.4 \mathrm{~mm}$. An orthomosaic with a resolution of $1 \mathrm{~mm}$ per pixel was produced by connecting these orthophotos, from which the effects of relief displacement and tilt have been removed. Using an orthomosaic similar to a map, the objects on the bedding surface are drawn with an accuracy of about $2 \mathrm{~mm}$ (Fig. 3a).

Footprints of the lower part of the cliff, however, were also traced on transparent plastic (Fig. 4). A Canon EOS M2 camera, the software package Agisoft Photo Scan Professional (Educational License), and Cloud Compare software were used (Falkingham, 2012; Falkingham et al., 2018).

No samples were collected, and the geometry of the footprints was measured on transparent paper, including footprint length (FL), footprint width (FW), pace angulation (PA), stride (S), trackway width (TW) and digit length (DL), following general conventions (Leonardi, 1987).

\section{Systematic ichnology}

\section{Ichnoorder Carnivoripedida (Vialov, 1966)}

Ichnogenus Felipeda (Panin and Avram, 1962)

\section{Emended diagnosis}

Plantigrade to semi-plantigrade footprints exhibiting four digits (II to V), each with a spheroidal to ovoid or elongate digital pad. The pads form a semicircle in front of, or in about the front portion of, the metatarsal pads. Digital pad III is often the most anterior, and there never appears to be lateral symmetry on an anterior/posterior (AP) line between digital pads III and IV. Digital pads may be of equal or similar size or may show limited dimensional variation. Impressions of claw tips may be present but are usually absent (emended by Sarjeant et al., 2002).

\section{Type ichnospecies}

Felipeda lynxi (Panin and Avram, 1962).

\section{Discussion}

Felipeda is known as four-digit imprints of carnivore footprints, which are distinguished by their round digit imprints without claw impressions. The type specimen of Felipeda lynxi is incomplete, and it does not include complete sole imprints (Panin and Avram, 1962, fig. 15). Thus, the assessment of Felipeda as plantigrade or digitigrade is important. Vialov (1965) introduced Bestiopeda as imprints of four digits, the rear pad $53 \mathrm{~mm}$ wide and $62 \mathrm{~mm}$ long in $B$. bestia (type ichnospecies), each digit imprint an elongate oval, digits close together and almost contiguous, imprint of first digit has a noticeably narrower anterior edge, and digits II and III project anteriorly in front of digits I and IV (Sarjeant et al., 2002). Aramayo and Manera de Bianco (1987), on the other hand, described felid footprints as digitigrade and medium sized with imprints of a subtrapezoidal to subtriangular palmar pad or plant and four digital pads. They named these footprints Pumaeichnum and attributed them to the living puma (Felis concolor) based on size and morphology. The diagnosis of Pumaeichnum can be emended to include plantigrade and semi-plantigrade to digitigrade, obligate quadruped tetradactyl feloid footprint impressions exhibiting four digits (II-V), each with a spheroidal to ovoidal digital pad forming a single semicircular arc in front of the interdigital pad, sole and heel impressions; digital pads are of equal or similar size, and impressions of claw tips are usually absent (Remeika, 2001). There are no significant differences between this diagnosis and the diagnosis of Felipeda by Sarjeant et al. (2002). Thus, Pumaeichnum has been considered a junior synonym of the ichnogenus Felipeda (Agnolin et al., 2019). Sarjeant et al. (2002) considered Pumaeichnum and Bestiopeda as junior synonyms of Felipeda.

Pantheraichnus is a large plantigrade felid footprint from the Late Pleistocene in Germany. It has four round-oval digit II-V pads imprinted in front of the large pad. In the best preserved imprint, this large pad is oval-shaped in the manus and more kidney-shaped or rectangular in the pes (Diedrich, 2011). Nevertheless, there are no morphological differences between Pantheraichnus and Felipeda, so it is another junior synonym of Felipeda.

Mitsupes Rodríguez-de la Rosa et GuzmánGutiérrez (2012) has been introduced for medium-sized felid footprints with asymmetrical metatarsal imprints. This asymmetry distinguishes this ichnogenus from the bilaterally symmetrical Felipeda.

Quiritipes Sarjeant et al. (2002) from the Eocene in Wyoming was named for semi-digitigrade to semiplantigrade mammalian footprints of ovoidal to lanceolate outline and a small to moderate size. The pes is somewhat larger than the manus. Four digits are imprinted; all are acuminate (though not acute) without claws. The lack of claw imprints suggests a non-canid trackmaker and differs from Felipeda by size and the age of the footprints, which are older than the first occurrence of Felidae in the Oligocene. 


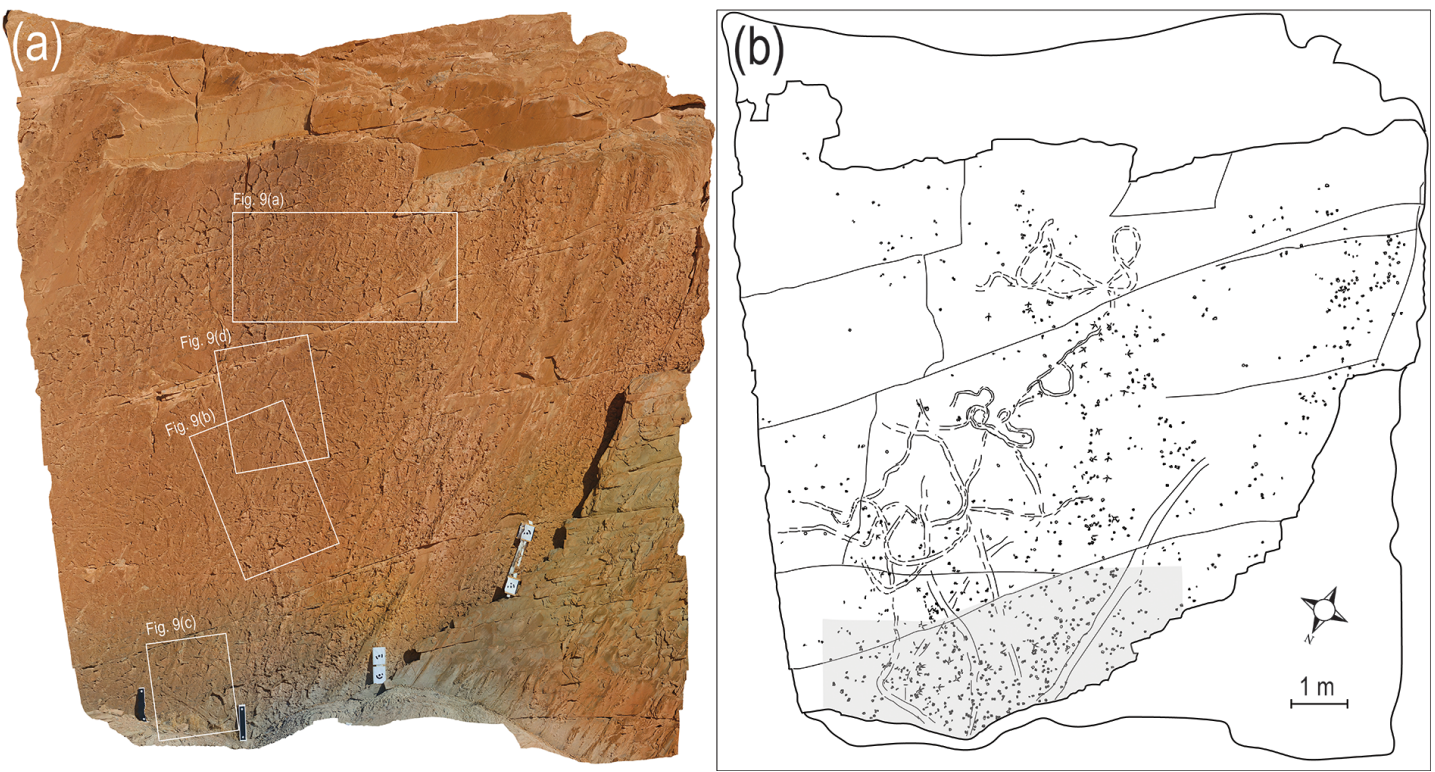

Figure 3. Outcrop of Chehrabad tracksite, photographed by the quadcopter UAV, and its sketch, extracted from high-resolution UAV photos. The lower highlighted part of the slab was traced on transparent plastic (Fig. 4). Scale bar represents $1 \mathrm{~m}$. Quadrangles show position of Fig. 9a-d.

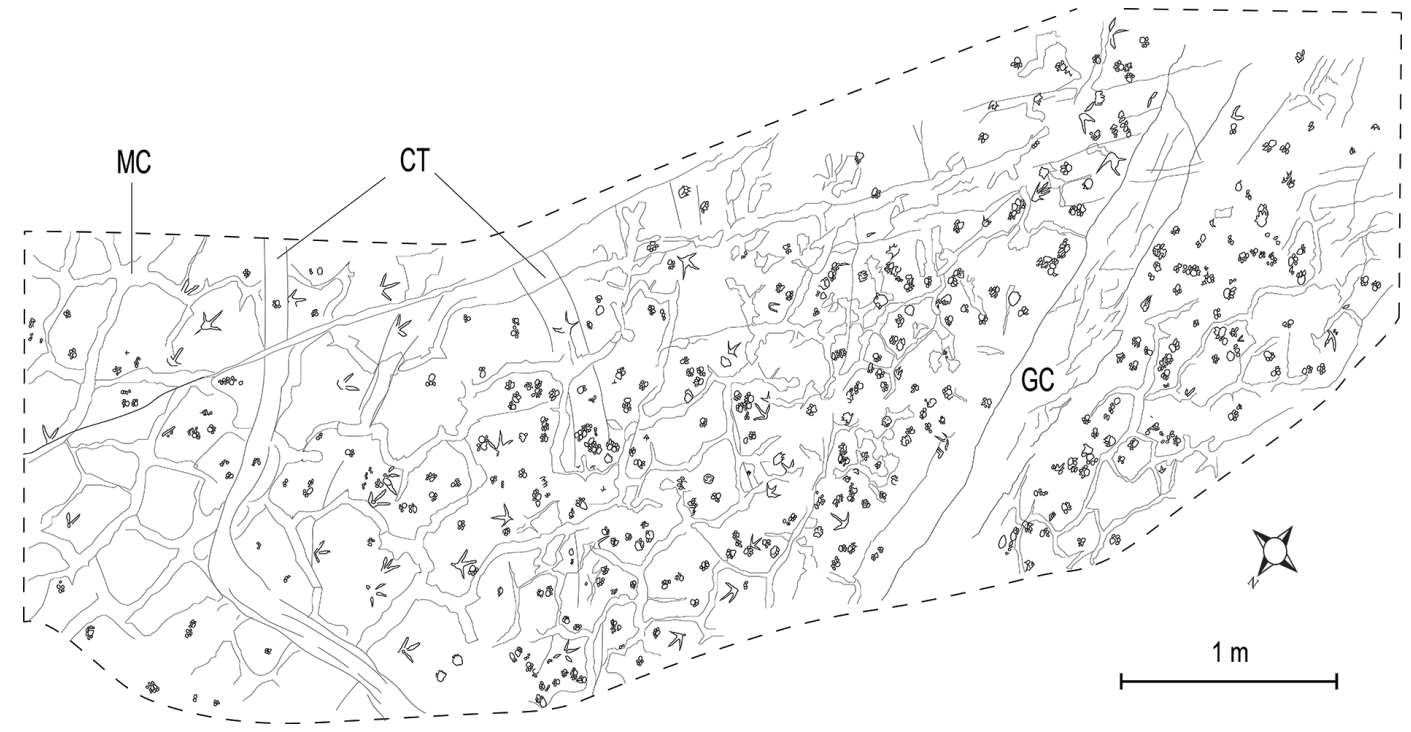

Figure 4. Carnivore and bird footprints in the lower part of the slab in detail: MC, mud-crack cast; GC, groove cast; CT, crawling trace.

The earliest felids appeared sometime between ca. $35 \mathrm{Ma}$ (age of the sister group) and $28.5 \mathrm{Ma}$ (minimum age of the earliest fossils) (Werdelin et al., 2010). The name Felipeda, however, has been used for Eocene carnivore footprints as a subichnogenus of Bestiopeda (Felipeda) by Scrivner and Bottjer (1986). Felipeda differs from Pycnodactylopus Sarjeant et al. (2002) in lacking broadly ovoid and broad digital impressions with two phalangeal pads.

Abbassi and Shakeri (2005) reported felid footprints from the URF of the Mushampa area and for the first time from
Iran and assigned them to Bestiopeda isp. In contrast, Abbassi and Amini (2008) reported poorly preserved felid footprints from the URF of the Eyvanekey section in eastern Tehran as Chelipus isp. Based on morphology and the lack of claw imprints, these reports are revised as Felipeda isp. 
Ichnospecies Felipeda lynxi (Panin and Avram, 1962)

Fig. 5

\section{Specimen}

Numerous footprints on the large slab, studied in the field and traced on transparent paper. There are 27 footprints arranged in six trackways measured on the lower part of the slab using transparent paper.

\section{Diagnosis}

Felidae footprint with four oval digit imprints separate from sole imprints. The footprint is $52 \mathrm{~mm}$ wide, and footprint length cannot be measured because the trace is not complete. The digit II and III imprints are closer to each other and have a frontal position in contrast to the lateral digits I and IV, so digit III is $3 \mathrm{~mm}$ forward of digit IV, and digit II is $2-3 \mathrm{~mm}$ forward of digit I. Digit imprints are $17 \times 12 \mathrm{~mm}$ in dimensions. Claw imprints are absent, suggesting that they were retractable. Footprints of Felis chaus and Lynx caracal are the closest analogies to the studied footprints (from Panin and Avram, 1962; translated from Romanian).

\section{Description}

These plantigrade footprints are Felidae footprints; fourdigital impressions are spheroidal to ovoid in shape, arranged in front of the metacarpal and metatarsal pad imprints. Metacarpal and metatarsal pads show conspicuous posterior indentations. A gap separates digits II-V from the metacarpal and metatarsal pads. The imprints of digits III-IV are larger and closer to each other. No claw imprints are visible. Table 1 shows dimensions of these footprints.

\section{Discussion}

Shape of the digit imprints, morphology and size of metatarsal and/or metacarpal imprints, span between digits and between metatarsal and/or metacarpal imprints, size comparison with living felids, and symmetry or asymmetry of the footprints are the main characters for ichnospecies identification of the ichnogenus Felipeda. Based on the new combination of Bestiopeda and Pumaeichnum as Felipeda, and the newly reassigned ichnospecies, there are eight valid ichnospecies of Felipeda: F. lynxi Panin 1965, F. biancoi Aramayo and Manera de Bianco, 1987, F. felis Panin 1965, F. milleri Remeika 1999, F. scrivneri Sarjeant et al. 2002, F. bottjeri Sarjeant et al. 2002, F. stouti (= Pumaeichnum stouti) (Remeika, 1999) and F. paryula (Anton et al., 2016). Kordos (1985) introduced Bestiopeda maxima for mammalian carnivore footprints of great size with the sole impression proximodistally flattened with five separate toe prints that are oval in plain view. Sarjeant et al. (2002) considered this as Felipeda maxima, a new combination. Indeed, this footprint comprises five digit imprints and it should be assigned to $\mathrm{Fe}$ lipeda.

Like this combination, Sarjeant et al. (2002) reclassified Bestiopeda sanguinolenta as Felipeda sanguinolenta, but Melchor et al. (2019) recombined it as Canipeda sanguinolenta.

Bestiopeda gracilis was considered as the type ichnospecies of Chelipus by Sarjeant and Langston (1994) and attributed to the Canidae. Vialov (1966) described B. gracilis as a small tetradactyl track, $35 \mathrm{~mm}$ long, $29 \mathrm{~mm}$ wide, with digits not in contact but fanned out, and with wide digits that are sharply pointed (clawed), and he identified it as the tracks of a small canid (Lucas, 2007). Pehuencoichnum gracilis Aramayo and Manera de Bianco (1987) has been combined with Chelipus (Remeika, 2001) because it has a footprint structure strikingly like that of a canid rather than of a felid, as originally assigned, and it is certainly referable to Chelipus as a member of this ichnogenus. A reexamination of photos of Pehuencoichnum shows that it has claw imprints and should be assigned to Canipeda (Melchor et al., 2019).

Sarjeant et al. (2002) considered Bestiopeda gracilis as $\mathrm{Fe}$ lipeda gracilis in a new combination. The photo of the holotype of B. gracilis shows exactly tapered digit imprints with a small metatarsal and/or metapodium and a gap between the digit and metatarsal and/or metapodium pad imprints. $\mathrm{Fe}$ lipeda lacks claw imprints or tapered digit imprints, so $B$. gracilis should not be combined with Felipeda.

In the last report of vertebrate footprints from the lower part of the slab studied here, 25 of the footprints were identified as Bestiopeda isp. (Khoshyar et al., 2016a). These footprints have spheroidal digital and metatarsal and/or metapodium pad impressions without claw imprints, so we assign them to Felipeda lynxi.

Ichnogenus Canipeda (Panin and Avram, 1962)

\section{Emended diagnosis}

Digitigrade to semi-digitigrade, tetradactyl, paraxonic, longer than wide footprints; arranged in quadrupedal and homopodial trackways. Elliptical, similar-sized and clawed digital pads form an arc in front of, and are well separated from, a large metapodial pad. Metapodial pad is rounded to triangular or trapezoidal (emended by Melchor et al., 2019).

\section{Type ichnospecies}

Canipeda longigriffa Panin and Avram, 1962.

\section{Discussion}

Canidae footprints are known as elongate footprints with claw marks that suggest non-retractable claws, a feature of canids. The digit imprints are close to each other with a symmetrical pattern along the AP line, and metatarsal and/or metacarpal imprints may be asymmetrical in the posterior lobe (Iliopoulos et al., 2012; Sarjeant et al., 2002). 

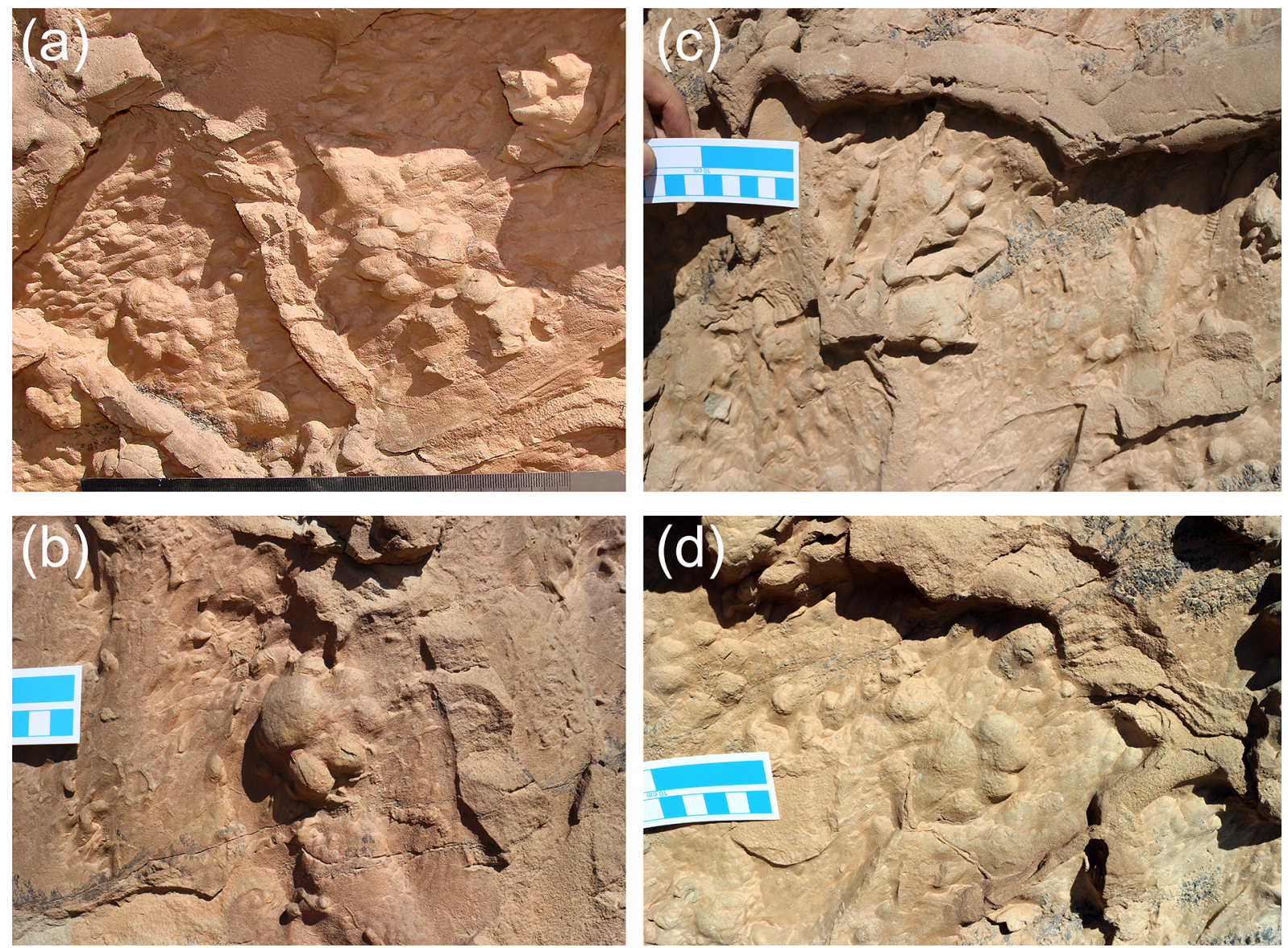

Figure 5. (a-d) Ichnospecies Felipeda lynxi photographed in the lower part of the slab of the tracksite, preserved as convex hyporelief. Scale equals millimeters $(\mathrm{mm})$ in (a) and centimeters $(\mathrm{cm})$ in $(\mathbf{b})-(\mathbf{d})$.

Table 1. Measurements on mammal and bird footprints in the lower part of the tracksite of Chehrabad.

\begin{tabular}{|c|c|c|c|c|c|c|c|c|c|c|c|c|c|c|c|}
\hline \multirow[t]{2}{*}{ Ichnospecies } & \multirow[t]{2}{*}{$\begin{array}{l}\text { Frequency of } \\
\text { measurements }\end{array}$} & \multirow[t]{2}{*}{$\begin{array}{r}\text { Stride } \\
(\mathrm{mm})\end{array}$} & \multirow[t]{2}{*}{$\begin{array}{r}\text { Pace } \\
(\mathrm{mm})\end{array}$} & \multirow{2}{*}{$\begin{array}{r}\text { Pace } \\
\text { angulation } \\
\text { ANG }\end{array}$} & \multirow{2}{*}{$\begin{array}{r}\text { Footprint } \\
\text { length } \\
\text { FL }(\mathrm{mm})\end{array}$} & \multirow{2}{*}{$\begin{array}{r}\begin{array}{r}\text { Footprint } \\
\text { width }\end{array} \\
\text { FW }(\mathrm{mm})\end{array}$} & \multicolumn{4}{|c|}{$\begin{array}{l}\text { Digit length } \\
(\mathrm{mm})\end{array}$} & \multicolumn{4}{|c|}{$\begin{array}{l}\text { Digit width } \\
\quad(\mathrm{mm})\end{array}$} & \multirow{2}{*}{$\begin{array}{r}\text { Trackway } \\
\text { width } \\
(\mathrm{mm})\end{array}$} \\
\hline & & & & & & & $L_{\mathrm{II}}$ & $L_{\mathrm{III}}$ & $L_{\mathrm{IV}}$ & $L_{\mathrm{V}}$ & $W_{\text {II }}$ & $W_{\text {III }}$ & $W_{\mathrm{IV}}$ & $W_{\mathrm{V}}$ & \\
\hline Felipeda lynxi & $\begin{array}{l}25 \text { footprints } \\
3 \text { trackways }\end{array}$ & 712 & 361 & $155^{\circ}$ & 51 & 49 & 16 & 16 & 16 & 16 & 12 & 12 & 12 & 11 & 120 \\
\hline Canipeda longigriffa & $\begin{array}{l}33 \text { footprints } \\
6 \text { trackways }\end{array}$ & 792 & 383 & $165^{\circ}$ & 57 & 58 & 20 & 20 & 21 & 19 & 13 & 13 & 14 & 14 & 69 \\
\hline
\end{tabular}

The tetradactyl, quadrupedal, digitigrade, paraxonic and homopodial tracks include Canipeda, Creodontipus, Quiritipes, Tetrastoibopus, and Bestiopeda (Melchor et al., 2019).

Tetrastoibopus was introduced for asymmetrical, plantigrade to semi-plantigrade footprints exhibiting four single small pads on the digits (II to V) and short claw imprints (Sarjeant and Langston, 1994). Carnotipus has large, asymmetrical tetra- to pentadactyl footprints with elongate imprints with tapered distal ends and without claw imprints (López et al., 1992). Sarjeant and Langston (1994) established Chelipus as a canid footprint and replaced it with Bestiopeda gracilis (Vialov, 1965). Canipeda differs from Bestiopeda either by larger size or by closely set, ovoid digit prints. Metatarsal pad imprints of Canipeda are larger, and the ratio of metatarsal pad length to footprint length (MPL / FL) is about 0.50. Bestiopeda, however, has a MPL / FL value of 0.36. Abbassi and Shakeri (2005) reported Creodontipus from URF in western Zanjan as a tetradactyl pes overprinted on the manus footprints without claw imprints: first Canidae footprints from the Aghajari Formation (late Miocene-Pliocene) in the Zagros Mountains, southern Iran, had been reported, and because of the presence of distinctive claw imprints, these were attributed to $\mathrm{Ca}$ nipeda (Abbassi, 2020b). 

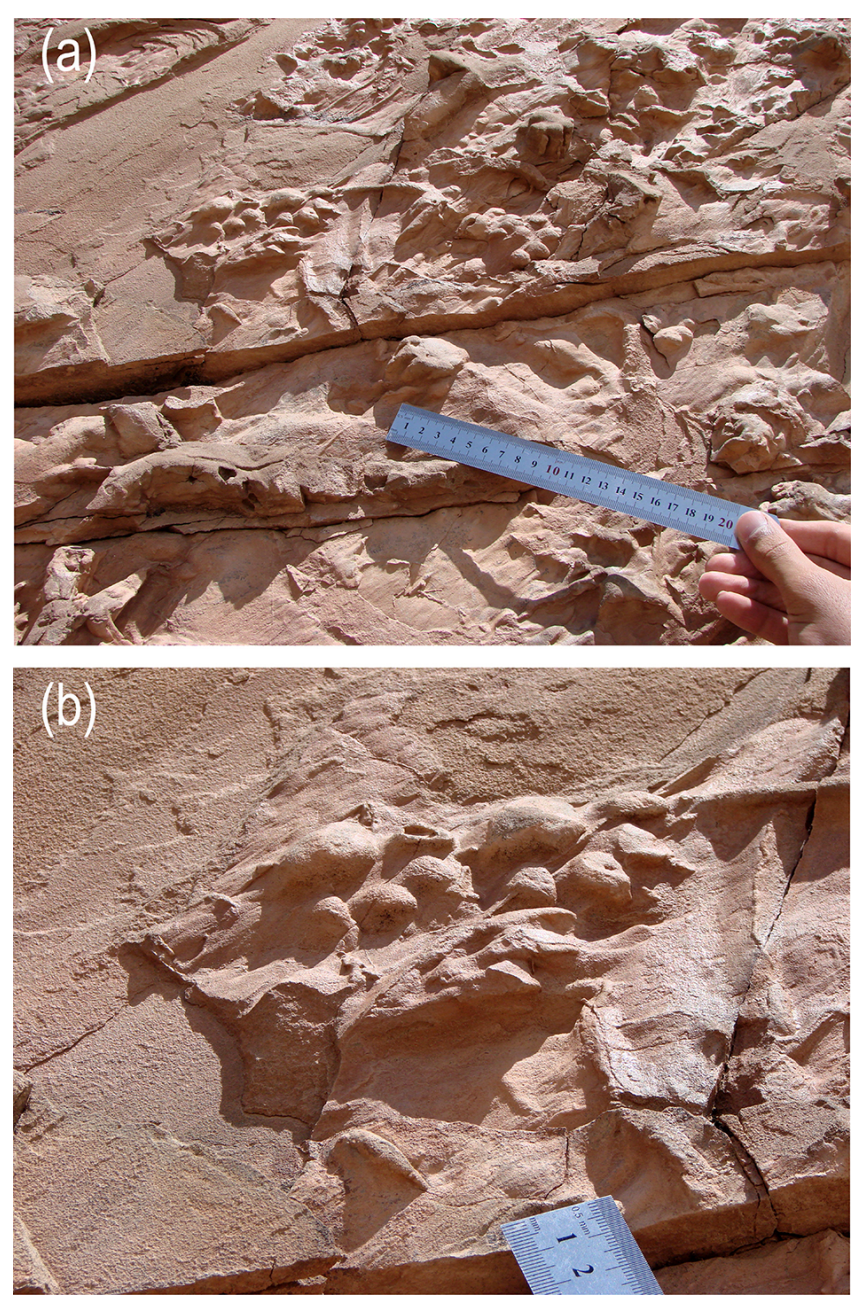

Figure 6. (a-b) Ichnospecies Canipeda longigriffa photographed in the lower part of the slab of the tracksite, preserved as convex hyporelief. Scales in centimeters $(\mathrm{cm})$.

Ichnospecies Canipeda longigriffa Panin and Avram, 1962

Fig. 6

\section{Specimens}

Numerous footprints in the studied slab. The geometry of six footprints in the lower part have been studied and measured.

\section{Diagnosis}

Canipeda footprints with four oval digital pads, closely spaced with distinctive claw footprints. Footprint length/width ratio is 1.6 to 1.9 , with low divarication of outer digits (II-V) less than $30^{\circ}$.

\section{Description}

Tetradactyl footprints with ellipsoidal or sub-spheroidal digit imprints, spread from large metapodial imprints. Middle digit imprints (III-IV) are longer than the lateral digit (II and V) imprints. Metatarsal/metapodium imprints are of the same size and heart shaped with two to three posterior lobes. Distinctive claw imprints are visible in front of the digit imprints (Fig. 7). The contact line of the claw imprint with the digit imprints is well preserved in some footprints. The positions of the claw imprints on digits III and IV are straight and inclined on lateral digits II and V. The claw imprint of digit III is aligned in front of the digit, and the claw imprint of digit IV, however, is inclined to the midline of the footprint. Positions of pes and manus imprints are not constant, and many pes imprints are overlapped on the manus imprints or separated from each other, or they are isolated footprints. Pes and manus imprints are of the same size. Table 1 shows the dimensions of these footprints.

\section{Discussion}

At first, Canipeda was established as a monospecific $C$. longigriffa, which includes elongate tetradactyl footprints with long claw imprints. Its claw imprints converge in the middle digit imprints and are straight in lateral digit imprints. Based on the presence or absence of claw imprints as a distinctive diagnostic feature, some of the Bestiopeda ichnospecies were revised in the new combination ichnospecies of Canipeda by Sarjeant et al. (2002). In addition to the type ichnospecies $(C$. longigriffa), there are three valid ichnospecies of the ichnogenus Canipeda (Melchor et al., 2019): C. gracilis (Vialov, 1965), C. sanguinolenta (Vialov, 1965) and C. therates (Remeika, 1999).

Canipeda gracilis is known as having larger manus than pes imprints and a footprint length/width ratio between 1.0 and 1.3, less than in C. longigriffa. The ichnospecies C. sanguinolenta (=Bestiopeda sanguinolenta Vialov, 1966) has relatively large, tetradactyl carnivore footprints with tapered digit imprints. $C$. therates is a small-sized footprint with small metatarsal pad imprints.

Hyaena footprints differ from canid footprints by their larger and closer digit imprints (Abi-Said and Abi-Said, 2007). Iliopoulos et al. (2012) reported tetradactyl footprints with large claw imprints from the late Miocene of Crete (Greece) that might be referred to a large-sized hyaena.

Anton et al. (2004), however, believe that assigning $C$. longigriffa to Canidae is incorrect because of the large size of the interdigital pad relative to the toe pads, as well as the detailed morphology of the interdigital pad. They attributed C. longigriffa to a herpestid (mongoose). To assess this idea requires the reexamination of the holotype of $C$. longigriffa, which is lost, so only its photo is available. 

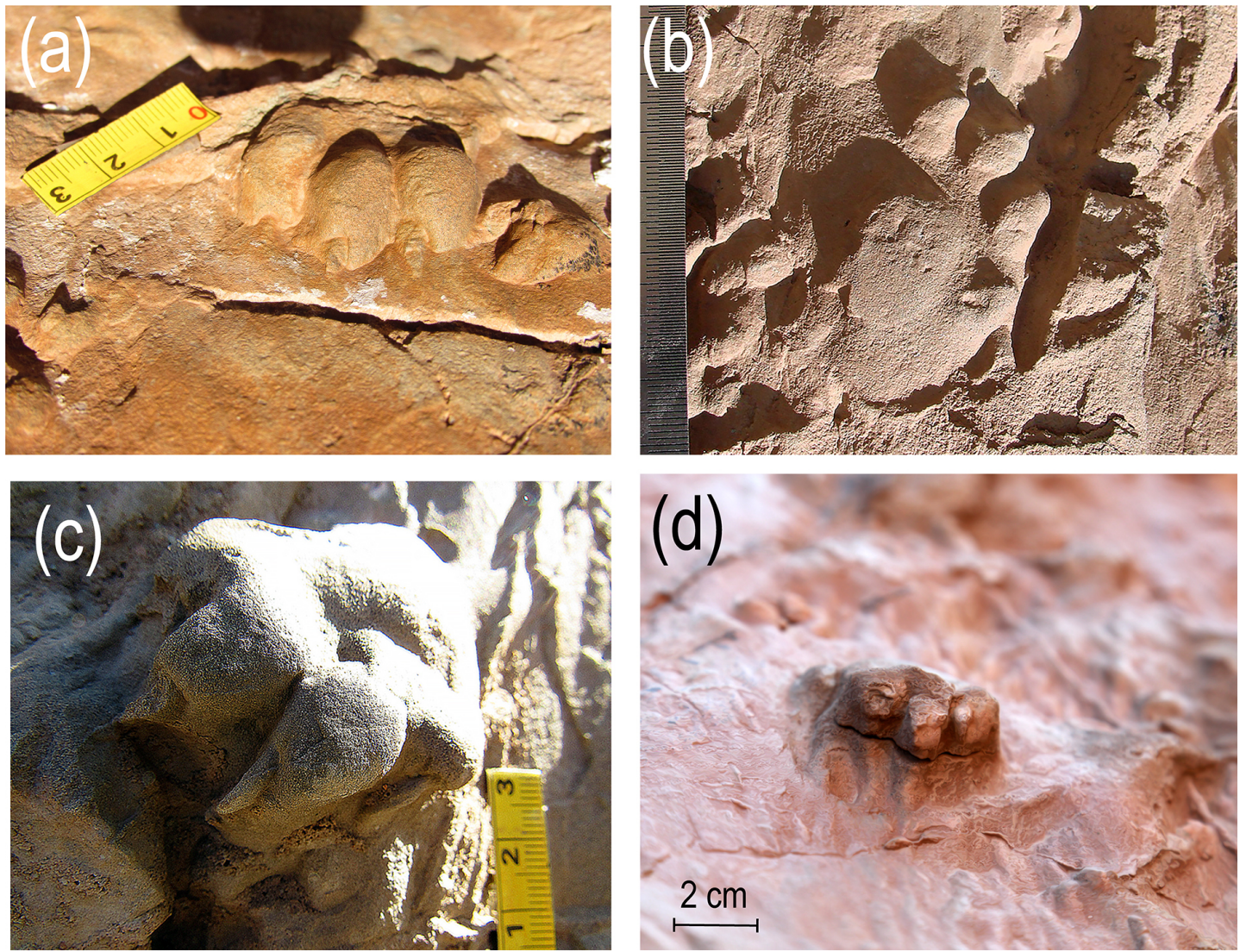

Figure 7. (a-d) Claw imprints of Canipeda longigriffa. Scale is in centimeters (cm) in (a)-(d), and scale bar equals $2 \mathrm{~cm}$ in (d).

Ichnoorder Avipedia Vialov 1961

Morphofamily Gruipedidae Sarjeant and Langston, 1994

Ichnogenus Iranipeda (Lambrecht, 1938)

\section{Emended diagnosis}

Large tetradactyl avian track with prominent broad, consistently diverging and acutely tapering digit impressions. Prominent heel pad and hallux impressions present. No traces of webbing present (Doyle et al., 2000).

\section{Type ichnospecies}

\section{Iranipeda abeli Lambrecht 1938}

\section{Discussion}

Large tetradactyl bird footprints have long been known from Miocene sediments. They include the Ardeipeda gigantea of Panin and Avram (1962), which is $23 \mathrm{~cm}$ long and $16.3 \mathrm{~cm}$ wide, and Iranipeda abeli, which is about $24 \mathrm{~cm}$ long and $22 \mathrm{~cm}$ wide (Lambrecht, 1938). Distinctively, Ardeipeda differs from Iranipeda by jointed digit imprints to the metapodium, and the hallux imprint is aligned to the digit III imprints. Also, the ratio of footprint length to hallux length of Iranipeda abeli (FL / DL hallux $=5.7)$ is greater than that of Ardeipeda gigantea $\left(\mathrm{FL} / \mathrm{DL}_{\mathrm{hallux}}=2.8\right)$. Avipeda filiportatis is large, four-digit tracks up to $19 \mathrm{~cm}$ long (Vialov, 1965), and Abbassi et al. (2020) reported large bird footprints from the late Miocene-Pliocene in northern Iraq with $22 \mathrm{~cm}$ length and $17 \mathrm{~cm}$ width. Lockley and Harris (2010), however, transferred Avipeda filiportatis to Ardeipeda filiportatis. Among these footprints, Iranipeda is large, tetradactyl avian footprints with prominent, broad, consistently diverging and acutely tapering digit impressions with circular heel imprints (Abbassi et al., 2020). Ardeipeda gigantea is characterized by connected and forward-directed digit imprints and backward-directed, long and isolated digit I imprints. Ardeipeda filiportatis shows distinctive circular heel imprints with connected, forward-directed digit imprints and has a shorter digit III than the lateral digit, and the hind digit I is much shorter (Vialov, 1989).

Sarjeant and Langston (1994) considered Iranipeda as a synonym of the ichnogenus Gruipeda Panin and Avram, 1962. However, Doyle et al. (2000) and Abbassi et al. (2015) concluded that Iranipeda is distinctive from Gruipeda and 
(a)
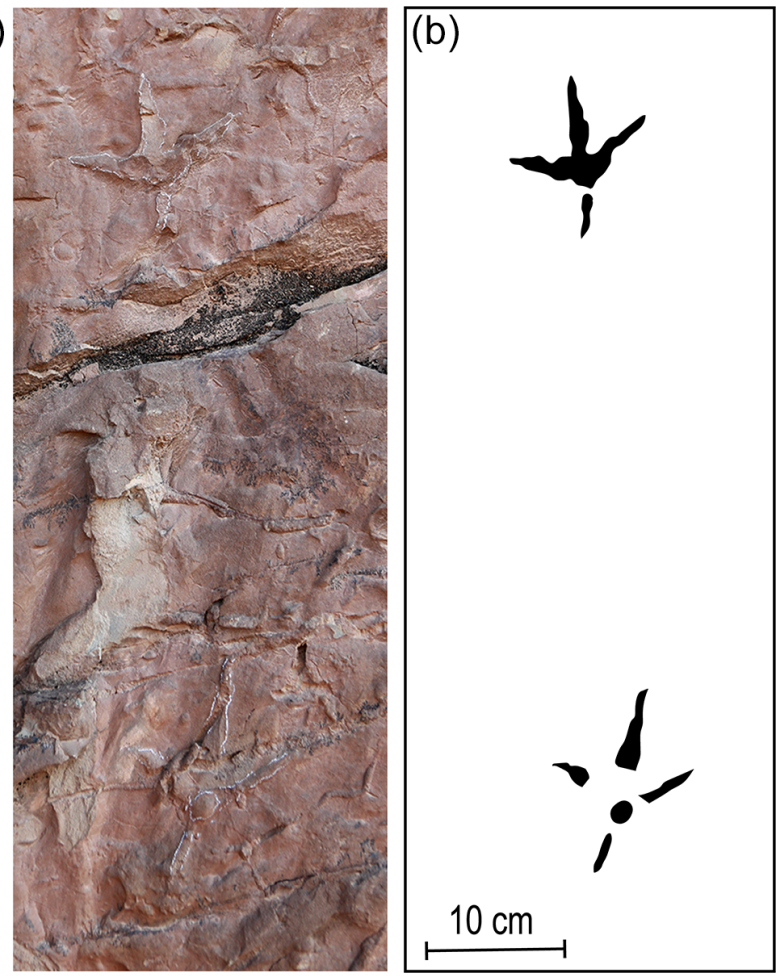

Figure 8. (a-b) Ichnospecies Iranipeda abeli trackway, preserved as convex hyporelief, and its sketch. Scale equals $10 \mathrm{~cm}$ and same for (a).

is a valid ichnogenus. Iranipeda are attributed to large birds with unwebbed feet, such as Ardeidae.

Ichnospecies Iranipeda abeli Lambrecht, 1938

Fig. 8

\section{Specimen}

Numerous bird footprints on the large slab, about 35 footprints mapped in the lower part of the slab.

\section{Diagnosis}

Large tetradactyl bird footprints with circular heel imprint and isolated and wide digit imprints. The digit III imprint is larger than the lateral digit imprints, and the digit I imprint is distinct. No interdigital webbing visible.

\section{Description}

Tetradactyl footprints with three straight, large, forwarddirected digit imprints and a smaller hind digit I imprint. Most of the footprints show isolated digit imprints with a distinctive circular heel imprint. Imbricated scale imprints are visible on some heel imprints. Three-digit pad imprints are visible in some of the footprints. Tips of digits are sharp without separate claw imprints.

\section{Discussion}

Three ichnospecies have been assigned to Iranipeda: I. abeli, I. millumi and I. intermedia (= Gruipeda intermedia Panin 1965, new combination by Doyle et al., 2000). I. abeli has wide digit imprints but a relatively shorter digit I than in Ardeipeda. The imprint of digit I of I. millumi is not clear. Doyle et al. (2000) reported tridactyl digit imprints like Iranipeda isp. with broad digits, identifiable heel impression and a relatively small size. The hallux (digit I) print is absent in this single tridactyl Iranipeda print. Based on the diagnosis of Iranipeda, it is difficult to assign it to Iranipeda. Panin (1965) introduced Gruipeda intermedia as large tetradactyl bird footprints $(\mathrm{FL}=15.5$ to $16 \mathrm{~cm})$ with slender digit imprints. Based on the size and the position of the digit imprints, it has been considered as an ichnospecies of Iranipeda intermedia in a new combination. Iranipeda intermedia definitely has isolated digit imprints with a circular heel imprint with a short digit I imprint. Iranipeda intermedia was mostly made by crane-like birds and are distinct from heron footprints, which show all the digits joined at a single spot and digit I that is short and rarely registers.

\section{Large grazing or locomotion traces}

\section{Description}

Numerous large grazing or locomotion traces are visible on the studied slab (Fig. 3). These trace fossils are preserved in convex hyporelief and were created first and then strongly affected by mud-cracks or trampled by vertebrate tracks, as well as, of course, by weathering after exposure. Thus, tracing the paths of these trails is difficult. These traces are straight and unbranched, curved, and with looping and selfcross-cutting and are subcylindrical in shape with large striations running along some of them. Sediment fill of the subcylinder is the same as the host rock sandstone. The width of the traces varies from 10 to $40 \mathrm{~cm}$ (mean $35 \mathrm{~cm}$ ), and the longest trail has a course that is $18 \mathrm{~m}$ long. The depth (relief) of the traces reaches 2 to $5 \mathrm{~cm}$. The rims of the traces are mostly ambiguous. One or two non-continues tubular bulges are preserved in the middle part or on both sides of the traces.

\section{Discussion}

The identification and interpretation of large burrows or trails is difficult, in either attributing them to distinct trace makers or distinguishing them from inorganic structures (Rodríguez-Tovar et al., 2008). The large burrows or trails in the Chehrabad tracksite are likely attributable to a relatively large animal grazing in or crawling on the sediment because of self-crossing or looping structures. Megapermichnus aliabadensis is an elongate, bifurcated and inclined structure from Permian sediments of the Alborz Mountains, which has been interpreted as being produced by a fish (Jenny and 
Jenny-Deshueese, 1978). Giant, tubular, unilobate trace fossils similar to Planolites in shape and design, but markedly larger in size, have been named Megaplanolites ibericus (Calvo et al., 1987).

Megagyrolithes asdescensis is a large spiral burrow attributed to crustaceans (Gaillard, 1980).

Myers et al. (2019), in an aquaria-based study, reported sedimentary structures resembling planar lamina and ripple cross lamina with grain sizes ranging from fine sand to gravel made by a sand-sifting goby, and they noted that these structures may have a long history in the geological record reflecting feeding styles and bio-resuspension behaviors of macrofauna from different time periods (Myers et al., 2019). Numerous gutter-like furrows, up to $60 \mathrm{~cm}$ wide and up to $9 \mathrm{~m}$ long, have been reported from the shallow Middle Jurassic sea floor from Liesberg, Switzerland, and interpreted as feeding traces made by large marine vertebrates, most likely plesiosaurs and ichthyosaurs searching for food in the lime mud (Geister, 1998).

The large traces described here resemble Megaplanolites, to which they are tentatively assigned, and may have been created by a large snake-like animal. Megaplanolites has been reported from shallow marine carbonate shelves to littoral conditions; however, the Chehrabad Megaplanolites was created in a continental environment. Distinctive features of the somewhat similar but small-scale cylindrical burrows, Planolites and Palaeophycus, were well discussed by Pemberton and Frey (1982) and Keighley and Pickerill (1995): Planolites is diagnosed primarily on the basis that it is an unlined simple burrow that was actively backfilled with sediment having textural and fabric-like characters unlike those of the host rock. In contrast, Palaeophycus is a lined burrow and represents passive sedimentation, filled with sediments typically identical to those of the surrounding matrix.

Some of the large traces described here show both characteristics of Planolites and Palaeophycus, including no distinctive wall or lining, sediment fill the same as the surrounding matrix and striations on the surface of some of the traces (Fig. 9). These large traces may be the crawling traces of a snake-like animal on the surface during the first phases after sedimentation. A snake crawling on sediment produces closed to open trails with lateral sediment deformations and striations of variable width (Abbassi, 2020a) (Fig. 10). The width variations of the traces described here, presence of striations, shape and self-crossing suggest that these trails may have been made by a snake or snake-like animal. This compression is not outlined by lateral sediment deformation, so crawling traces show sharp and unique rims with surrounding sediments. Usually, forces generated by snakes are using variable numbers of points for lateral undulation movement across a flat surface (arrows in the sketch of Fig. 10). Thus, the relief of a crawling impression may differ along the trace, which may not be present in the studied traces. Further study of these traces is planned.

\section{Discussion}

Despite the abundant plant fossils in the studied area, unfortunately there are no paleobotanical studies in the URF. A few and sparse herb, reed and tree trunk fossils have been identified in the study area (Fatemeh Vaez Javadi, personal communication, 2020). An early Miocene gymnosperm tree trunk fossil has been reported in the Ardabil area, northern Zanjan Province, northwest Iran (Mustoe et al., 2020). Thus, it seems that around the playa and the pond sedimentary environments of the URF, there was grassland meadow vegetation. Abundant middle Miocene carnivore and herbivores lived in the savanna plain of the URF environment.

Based on previous reports, Miocene trackmakers of the URF include carnivores (felids, Creodonta, mustelids, canids), birds (Charadriiformes, Anseriformes, Gruiformes, Ciconiiformes) and herbivores (artiodactyls, proboscideans) (Abbassi, 2010; Abbassi and Amini, 2008; Abbassi and Shakeri, 2005; Alavi et al., 2016; Khoshyar et al., 2016a, b). The tracksite of the URF in Chehrabad studied here comprises abundant imprints of canids and felids with sparse bird footprints. The mean length of the canid footprints in the lower part of this tracksite is $57 \mathrm{~mm}$ with a FL / FW ratio $(57 / 58 \mathrm{~mm})$ of 0.98 , which is less than the known ichnospecies of Canipeda (Melchor et al., 2019). Today, canids are cosmopolitan mammals, but they were restricted to North America for all of their early history, not reaching the Old World until the Miocene at the latest. The oldest and most primitive canids are the Hesperocyoninae of the late middle Eocene (Duchesnean) to the middle Miocene (Barstovian) in North America (Rose, 2006; Wang, 1994). Canidae was not present in Europe until the Miocene and not in Asia and Africa until the late Miocene (Kemp and Kemp, 2005). Late Miocene Vulpes riffautae is the oldest Canidae fossil from Africa (De Bonis et al., 2007). The migration of Canidae from North America to Eurasia and their first appearance in Eurasia is known as the "Eucyon event", which occurred in the late Miocene (Sotnikova and Rook, 2010; Rook, 2009; Sotnikova, 2010). The late Miocene Maragheh fauna in northwest Iran is a well-known late Miocene faunal site (Bernor, 1985; Kostopoulos, 2009). Canidae fossils, however, have not been reported from this pre-eminent vertebrate fossil site. The numerous Canidae footprints from the Chehrabad tracksite are the first reported Canidae fossil remains from the Iranian Plateau, and they occur during the Tortonian.

The earliest records of felids are from the Oligocene; the genus Proailurus appears just after the end of the Eocene in Eurasia and expands to other continents in the late Miocene (Goswami and Friscia, 2010; Johnson et al., 2006; Gaubert and Veron, 2003). The early-middle Miocene radiation of Felidae is complex, so Pseudaelurus is reported from Europe, Arabia, China and North America (Werdelin et al., 2010). Felis attica, Metailurus orientalis and Amphimachairodus aphanistus are Felidae from the middle and up- 

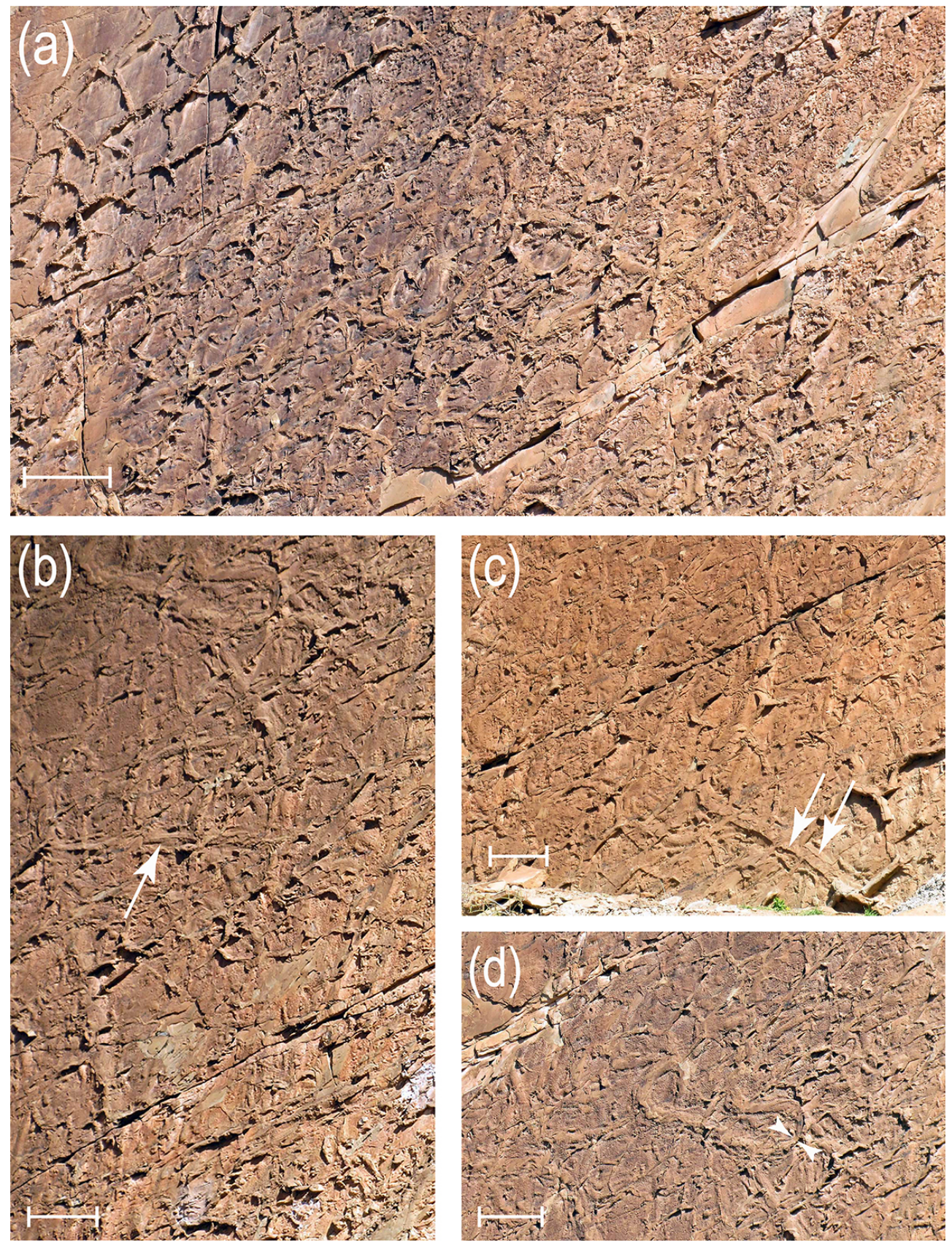

Figure 9. (a-d) Grazing and locomotion traces on the studied slab. (a) Regular trace, (b-c) straight to slightly curved traces with one or two non-continues tubular bulges being preserved in the middle part or both sides of the traces (arrows), and (d) self-crossing of trace with width variations. Arrows show minimum of the width. Scale bars represent $1 \mathrm{~m}$.

per parts of the Maragheh Formation (8.16-7.4 Ma), and the latter two felids are of large size (Bernor, 1986; Ataabadi et al., 2013). In contrast, the felid footprints documented here are relatively small in size: $\mathrm{FL}=61 \mathrm{~mm}, \mathrm{FW}=59 \mathrm{~mm}$, and FL / FW equals 1.03. These felid footprints are smaller in size then the Mushampa sample (=Bestiopeda isp.; Abbassi and Shakeri, 2005): $\mathrm{FL}=125 \mathrm{~mm}, \mathrm{FW}=118 \mathrm{~mm}$, and FL / FW equals 1.05. Overall, the felid footprints are fewer in number than the canid footprints in the studied slab. Nevertheless, they represent an important regional record of felids.

\section{Conclusion}

The tracksite of Chehrabad is one of the numerous vertebrate tracksites of the URF in the west of Zanjan Province. The URF was deposited in a continental playa-like environment, 

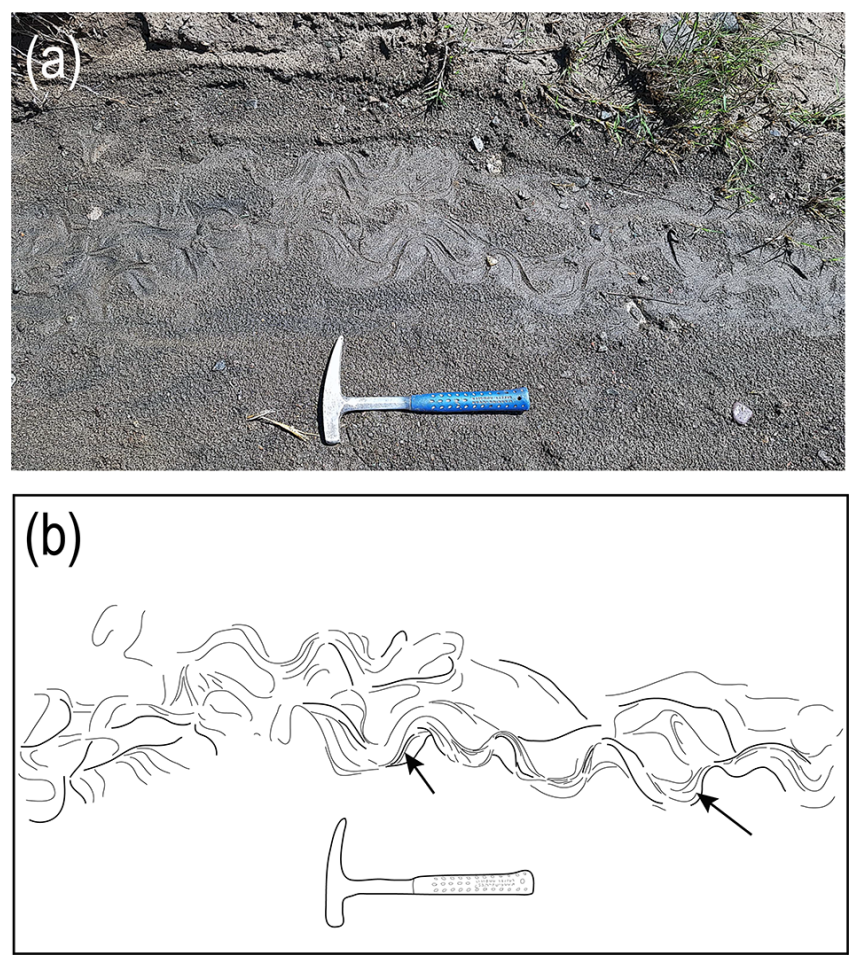

Figure 10. Recent snake trails on creek sediments. Arrows show lateral pressures during the crawling of snakes (Abbassi, 2020). Length of hammer equals $30 \mathrm{~cm}$.

with braided to meandering rivers and ephemeral ponds under a warm climate during the middle to late Miocene. The studied large slab contains abundant carnivore footprints mostly arranged in a track corridor. In addition to sparse large bird footprints, Iranipeda abeli, numerous canid footprints are attributable to Canipeda longigriffa and felid footprints to Felipeda lynxi. The presence of canid footprints confirms that the first appearance of the Canidae in Eurasia was no later than the late Miocene. In this track corridor, a grazing or crawling snake-like animal produced a trace tentatively attributed to Megaplanolites, which formed in a continental setting.

Data availability. All data are available from the senior author (Nasrollah Abbassi, abbasi@znu.ac.ir or nasrabbassi@gmail.com).

Author contributions. NA and MK collected the investigated material in the field. NA identified ichnotaxa and prepared the manuscript. SGL improved the ichnotaxonomy and edited the manuscript in the English language. FE performed the UAV photogrammetry and accurate 3D modeling and orthomosaic of the studied slab.
Competing interests. The authors declare that they have no conflict of interest.

Acknowledgements. We would like to thank Martin Lockley and the anonymous reviewer for their thorough reviews which improved the present paper. Photo of Fig. 8 courtesy of Lida Xing; he photographed it when he visited Chehrabad tracksite in 2015. The authors thank Mahdis Abbassi and Mohammad Rastin Abbassi, who helped us in the field studies. We also thank Afshin Zohdi and Zahra Alavi for their assistance.

Review statement. This paper was edited by Florian Witzmann and reviewed by Martin Lockley and one anonymous referee.

\section{References}

Abaie, I., Ansari, H. J., Badakhshan, A., and Jaafari, A.: History and development of the Alborz and Sarajeh fields of Central Iran, Bulletin of Iranian Petroleum Institute, 15, 561-574, 1964.

Abbassi, N.: Vertebrate Footprints from the Miocene Upper Red Formation, Shokorchi Area, Zanjan Province, NW Iran, Ichnos, 17, 115-126, 2010.

Abbassi, N.: Trace Fossils, Concepts and Applications, University of Zanjan publications, Zanjan, Iran, 2020a.

Abbassi, N.: Carnivora tracks from the Agha Jari Formation (Upper Miocene-Pliocene), Bibi Hakimeh anticline, Zagros Mountains, Symposium of Geological Society of Iran, Geological Society of Iran publications, Tehran, Iran, 2020b.

Abbassi, N. and Amini, A.: Ichnology of Miocene vertebrate footprints in the Upper Red Formation, Evan-e-key section, east Tehran, Iran, Geological Survey of Iran Scientific Quarterly Journal of Geoscience, 67, 56-67, 2008.

Abbassi, N. and Shakeri, S.: Miocene vertebrate footprints from the Upper Red Formation, Mushampa area, Zanjan province, Scientific Quarterly Journal of Geoscience, 12, 76-89, 2005.

Abbassi, N., Lucas, S. G., and Zaare, G. R.: First report of Oligocene vertebrate footprints from Iran, Palaeogeogr. Palaeocl., 440, 78-89, 2015.

Abbassi, N., Karim, K. H., Mohialdeen, I. M. J., and Sharbazheri, K. M.: Vertebrate footprints and a mammal mud-bath trace fossil (Laspichnia) from the Mukdadiya Formation (Late MiocenePliocene), Chamchamal Area, Kurdistan Region, Northeast Iraq, Ichnos, 28, 72-83, 2020.

Abi-Said, M. R. and Abi-Said D. M.: Distribution of the Striped Hyaena (Hyaena hyaena syriaca Matius, 1882) (Carnivora: Hyaenidae) in urban and rural areas of Lebanon, Zool. Middle East, 42, 3-14, 2007.

Aghanabati, A.: Geology of Iran, Geological Survey of Iran, Terhran, Iran, 2004

Agnolin, F. L., Chimento, N. R., Campo, D. H., Magnussen, M., Boh, D., and De Cianni, F.: Large Carnivore Footprints from the Late Pleistocene of Argentina, Ichnos, 26, 119-126, 2019.

Alavi, M.: Regional stratigraphy of the Zagros fold-thrust belt of Iran and its proforeland evolution, Am. J. Sci., 304, 1-20, 2004.

Alavi, Z., Abbassi, N., and Afshin, Z.: Ichnology of the seabird and shorebird footprints around the Miocene playa basins, an effort 
for paleoecology reconstruction of Upper Red Formation in the west of Zanjan province, 2nd Symposium of Sedimentological Scoiety of Iran, University of Ferdowsi, Mashhad, Iran, 2016.

Amini, A.: Provenance and Depositional Environment of the Upper Red Formation, Central Zone Iran, The University of Manchester, 1997.

Amini, A.: Red colouring of the Upper Red Formation in central part of its basin, central zone, Iran, Journal of Sciences Islamic Republic of Iran, 12, 145-156, 2001.

Anton, M., López, G., and Santamaria, R.: Carnivore Trackways from the Miocene Site of Salinas de Añana (Alava, Spain), Ichnos, 11, 371-384, 2004.

Anton, M., López, G., and Santamaria, R.: Carnivore Trackways from the Miocene Site of Salinas de Añana (Alava, Spain), Ichnos, 11, 371-384, 2016.

Aramayo, S. A. and Manera de Bianco, T.: Hallazgo de una icnofauna continental (Pleistoceno tardío en la localidad de PehuenCo (partido de Coronel Rosales), Provincia de Buenos Aires, Argentina. Pt. 1, Edentata, Litopterna, Proboscidea. Pt. 2, Carnivora, Artiodactyla y Aves: Congresso Latinoamericano Paleontologia (Bolivia), 1, 516-531, 532-547, 1987.

Ataabadi, M. M., Bernor, R. L., Kostopoulos, D. S., Wolf, D., Orak, Z., Zare, G., Nakaya, H., Watabe, M., and Fortelius, M.: Recent advances in paleobiological research of the late Miocene Maragheh Fauna, Northwest Iran, in: Fossil Mammals of Asia, edited by: Wang, X., Flynn, L. J., and Fortelius, M., 546-565, Columbia University Press, New York, 2013.

Ballato, P., Nowaczyk, N. R., Landgraf, A., Strecker, M. R., Friedrich, A., and Tabatabaei, S. H.: Tectonic control on sedimentary facies pattern and sediment accumulation rates in the Miocene foreland basin of the southern Alborz mountains, northern Iran, Tectonics, 27, TC6001, https://doi.org/10.1029/2008TC002278, 2008.

Ballato, P., Mulch, A., Landgraf, A., Strecker, M. R., Dalconi, M. C., Friedrich, A., and Tabatabaei, S. H.: Middle to late Miocene Middle Eastern climate from stable oxygen and carbon isotope data, southern Alborz mountains, N Iran, Earth Planet. Sc. Lett., 300, 125-138, 2010.

Ballato, P., Cifelli, F., Heidarzadeh, G., Ghassemi, M. R., Wickert, A. D., Hassanzadeh, J., Dupont-Nivet, G., Balling, P., Sudo, M., Zeilinger, G., Schmitt, A. K., Mattei, M., and Strecker, M. R.: Tectono-sedimentary evolution of the northern Iranian Plateau: insights frommiddle-late Miocene foreland-basin deposits, Basin Res., 29, 417-446, https://doi.org/10.1111/bre.12180, 2017.

Bernor, R. L.: Systematic and evolutionary relationships of the hipparionine horses from Maragheh, Iran (late Miocene, Turolian age), Palaeovertebrata, 15, 173-269, 1985.

Bernor, R. L.: Mammalian biostratigraphy, geochronology, and zoogeographic relationships of the Late Miocene Maragheh fauna, Iran, J. Vertebr. Paleontol., 6, 76-95, 1986.

Calvo, J., Gil, E., and Meléndez, G.: Megaplanolites ibericus (ichnogen. et ichnosp. nov.), a new trace fossil from the Upper Jurassic (uppermost Oxfordian) of Bueña (Teruel Province, Iberian Chain, Spain), Palaeogeogr. Palaeocl., 61, 199-204, 1987.

Cronin, T. M.: Paleoclimates: understanding climate change past and present, Columbia University Press, New York, 2009.
Daneshian, J. and Ramezani Dana, L.: Early Miocene benthic foraminifera and biostratigraphy of the Qom Formation, Deh Namak, central Iran, J. Asian Earth Sci., 29, 844-858, https://doi.org/10.1016/j.jseaes.2006.06.003, 2007.

De Bonis, L., Peigné, S., Likius, A., Mackaye, H. T., Vignaud, P., and Brunet, M.: The oldest African fox (Vulpes riffautae n. sp., Canidae, Carnivora) recovered in late Miocene deposits of the Djurab desert, Chad, Naturwissenschaften, 94, 575-580, 2007.

Diedrich, C. G.: Late Pleistocene steppe lion Panthera leo spelaea (Goldfuss, 1810) footprints and bone records from open air sites in northern Germany-evidence of hyena-lion antagonism and scavenging in Europe, Quaternary Sci. Rev., 30, 1883-1906, 2011.

Doyle, P., Wood, J. L., and George, G. T.: The shorebird ichnofacies: an example from the Miocene of southern Spain, Geol. Mag., 137, 517-536, 2000.

Falkingham, P. L.: Acquisition of high resolution three-dimensional models using free, open-source, photogrammetric software, Palaeontol. Electron., 15, 1-15, 2012.

Falkingham, P. L., Bates, K. T., Avanzini, M., Bennett, M., Bordy, E. M., Breithaupt, B. H., Castanera, D., Citton, P., DíazMartínez, I., and Farlow, J. O.: A standard protocol for documenting modern and fossil ichnological data, Palaeontology, 61, 469-480, 2018.

Gaillard, C.: Megagyrolithes ardescensis n. gen., n. sp., trace fossile nouvelle du Valanginien d'Ardeche (France), Geobios, 13, 465471, 1980.

Gansser, A.: New Aspects of the Geology in Central Iran, Proceedings of the Fourth World Petroleum Congress, Rome, Italy, 1955.

Gaubert, P. and Veron, G.: Exhaustive sample set among Viverridae reveals the sister-group of felids: the linsangs as a case of extreme morphological convergence within Feliformia, P. Roy. Soc. Lond. B Bio., 270, 2523-2530, 2003.

Geister, J.: Lebensspuren made by marine reptiles and their prey in the Middle Jurassic (Callovian) of Liesberg, Switzerland, Facies, 39, 105-124, 1998.

Goswami, A. and Friscia, A.: Carnivoran evolution: new views on phylogeny, form and function, Cambridge University Press, Cambridge, 2010.

Iliopoulos, G., Roussiakis, S., and Fassoulas, C.: First occurrence of carnivore footprint with hyaenid affinities from the Late Miocene of Crete (Greece), Palaeobio. Palaeoenv., 92, 265-271, 2012.

Jenny, J. P. and Jenny-Deshueese, C.: Sur la presence de Megapermichnus ichnogen. nov. nouvel ichnogenre de taille géante dans le Permien de l'Elbourz oriental (Iran), Eclogae Geologicae Helveticae, 71, 313-319, 1978.

Johnson, W. E., Eizirik, E., Pecon-Slattery, J., Murphy, W. J., Antunes, A., Teeling, E., and O'Brien, S. J.: The late Miocene radiation of modern Felidae: a genetic assessment, Science, 311, 73-77, 2006.

Keighley, D. G. and Pickerill, R. K.: The ichnotaxa Palaeophycus and Planolites: Historical perspectives and recommendations, Ichnos, 3, 301-309, 1995.

Kemp, T. S. and Kemp, T.: The origin and evolution of mammals, Oxford University Press on Demand, Oxford, 2005.

Khoshyar, M., Abbassi, N., and Zohdi, A.: Ichnology of the Gruiformes coastal bird footprint from Upper Red Formation (Miocene), Hesar region, west of the Zanjan Province, 35th Na- 
tional Geosciences Congress, Tehran, Iran, Geological Survey of Iran publication, Tehran, 2016a.

Khoshyar, M., Abbassi, N., and Zohdi, A.: Reconstruction of Miocene diverse Carnivores distribution in the northwestern Iran: ichnological new data from Upper Red Formation, Zanjan Province 35th National Geosciences Congress, Tehran, Iran, Geological Survey of Iran publication, Tehran, 2016b.

Kordos, L.: Lábnyomok az ipolytarnóci alsó-miocén korú homokköben, Geologica Hungarica, 46, 259-415, 1985.

Kostopoulos, D.: The Pikermian Event: temporal and spatial resolution of the Turolian large mammal fauna in SE Europe, Palaeogeogr. Palaeocl., 274, 82-95, 2009.

Lambrecht, K.: Urmiornis abeli n. sp., eine Pliozäne Vogelfährte aus Persien, Palaeobiologica, 6, 242-245, 1938.

Leonardi, G.: Glossary and Manual of Tetrapod Footprint Palaeoichnology, Departamento Nacionalde Producao Mineral, Brasilia, 1987.

Lockley, M. G. and Harris, J.: On the trail of early birds: A review of the fossil footprint record of avian morphological and behavioral evolution, in: Trends in Ornithology Research (Birds - Evolution, Behavior and Ecology), edited by: Ulrich, P. K. and Willett, J. H., Nova Publishers, Hauppauge, NY, 1-63, 2010.

Lotfi, M.: Geological survey and mineral reserves in Geological Map 1:100,000 Mahneshan quadrangle (west Zanjan province, northwest Iran), Geological Survey of Iran, Tehran, Iran, sheet number 5563, 2001.

López, G., Mayoral, E., Muñoz, A., Pérez, A., and Sanatamaría, R.: Nuevas icnitas de mamíferos carnívoros en el Mioceno inferior del sector occidental de la depresión del Ebro (Logroño, La Rioja), Rev. Soc. Geol. España, 5, 31-51, 1992.

Lucas, S. G.: Cenozoic vertebrate fooptints ichnotaxa named by O. S. Viyalov in 1965 and 1966, New Mexico Museum of Natural History and Science Bulletin, 42, 113-148, 2007.

Melchor, R. N., Feola, S. F., and de Bianco, T. M.: Canid Paleoichnology: Taxonomic Review and producers of Canipeda from the late Pleistocene of Argentina, Ichnos, 26, 85-107, 2019.

Mohammadi, E.: Sedimentary facies and depositional environments of the Oligocene-early Miocene marine Qom Formation, Central Iran Back-Arc Basin, Iran (northeastern margin of the Tethyan Seaway), Carbonate. Evaporite., 35, 1-29, 2020.

Morley, C. K., Kongwung, B., Julapour, A. A., Abdolghafourian, M., Hajian, M., Waples, D. J. W., Otterdoom, H., Srisuriyon, K., and Kazemi, K.: Structural development of a major late Cenozoic basin and transpressional belt in central Iran: The Central Basin in the Qom-Saveh area, Geosphere, 5, 325-362, https://doi.org/10.1130/GES00223.1, 2009.

Mostofi, B. and Frei, E.: The main sedimentary basins of Iran and their oil possibilities, Proceedings, 5th World Petroleum Congress, World Petroleum Council Publications, New York, 1959.

Mustoe, G. E., Abbassi, N., Hosseini, A., and Mahdizadeh, Y.: Neogene Tree Trunk Fossils from the Meshgin Shahr Area, Northwest Iran, Geosciences, 10, 283, https://doi.org/10.3390/geosciences10080283, 2020.

Myers, R. A., Gingras, M. K., Keyes, G., Konhauser, K. O., and Zonneveld, J.-P.: Bioresuspension behaviors of the gobiid, Valenciennea puellaris, and the biogenic sedimentary structures it produces, Palaios, 34, 179-189, 2019.
NIOC (National Iranian Oil Company): Geological map of Iran, 1:2500000, National Iranian Oil Company publication, Tehran, 1959.

Okhravi, R.: Synsedimentary cementation in the Lower Miocene reefal carbonates of the central basin, Iran, Carbonate. Evaporite., 13, 136-144, 1998.

Panin, N.: Coexistence de traces de pas de vertébrés et de mécanoglyphes dans le Molasse Miocène des Carpates orientales, Revue Roumaine de Géologie, Géophysique, et Géographie, 7, 141$163,1965$.

Panin, N. and Avram, E.: Noi urme de vertebrate in Miocenul Subcarpatilor Rominesti, Studii si Cercetari de Geologie, 7, 455484, 1962.

Pemberton, S. G. and Frey, R. W.: Trace fossil nomenclature and the Planolites-Palaeophycus dilemma, J. Paleontol., 56, 843-881, 1982.

Rafiei, B., Ghomi, F. A., and Shahkaram, M.: Depositional environments and sequence stratigraphy of the fluvial Upper Red Formation (Miocene) in the Avaj area, Qazvin Province, Iran, Neues Jahrbuch für Geologie und Paläontologie-Abhandlungen, 259, 257-270, 2011.

Rahimzadeh, F.: Oligocene, Miocene, Pliocene, Geology of Iran, edited by: Houshmandzadeh, A., Geological Survey of Iran, Tehran, 1994.

Remeika, P.: Identification, stratigraphy, and age of neogene vertebrate footprints from the vallecito-fish creek basin, anza-borrego desert state park, california, San Bernardino County Museum Association Quarterly, 46, 37-46, 1999.

Remeika, P.: The fish creek canyon ichnofauna: a pliocene (blancan) vertebrate footprint assemblage from anza-borrego desert state park, california, Proceedings of the 6th Fossil Resource Conference: Lakewood, Colorado, USA, Geologic Resources Division Technical Report, 55-75, 2001.

Reuter, M., Piller, W., Harzhauser, M., Mandic, O., Berning, B., Rögl, F., Kroh, A., Aubry, M.-P., Wielandt-Schuster, U., and Hamedani, A.: The Oligo-/Miocene Qom Formation (Iran): evidence for an early Burdigalian restriction of the Tethyan Seaway and closure of its Iranian gateways, Int. J. Earth Sci., 98, 627650, 2009.

Rodríguez-Tovar, F. J., Puga-Bernabéu, Á., and Buatois, L. A.: Large burrow systems in marine Miocene deposits of the Betic Cordillera (Southeast Spain), Palaeogeogr. Palaeocl., 268, 1925, 2008.

Rook, L.: The wide ranging genus Eucyon Tedford \& Qiu, 1996 (mammalia, carnivora, canidae, canini) in the mio-pliocene of the old world, Geodiversitas, 31, 723-741, 2009.

Rose, K. D.: The beginning of the age of mammals, The Johns Hopkins University Press, Baltimore, Maryland, 2006.

Sarjeant, S. A. W. and Langston, J. W.: Vertebrate footprints and invertebrate traces from the Cadronian (Late Eocene) of TransPecos Texas, Texas Memorial Museum, The University of Texas at Austin, Austin, 86 pp., 1994.

Sarjeant, W., Reynolds, R., and Kissell-Jones, M.: Fossil creodont and carnivore footprints from California, Nevada, and Wyoming, Between the Basins: Exploring the Western Mojave and Southern Basin and Range Province, California State University, 2002.

Schuster, F. and Wielandt, U.: Oligocene and Early Miocene coral faunas from Iran: Palaeoecology and 
palaeobiogeography, Int. J. Earth Sci., 88, 571-581, https://doi.org/10.1007/s005310050285, 1999.

Scrivner, P. J. and Bottjer, D.: Neogene avian and mammalian tracks from Death Valley National Monument, California: their context, classification and preservation, Palaeogeogr. Palaeocl., 57, 285331, 1986.

Sotnikova, M.: Major biotic events related to the dispersal and evolution of Canidae durind the Pliocene and Pleistocene in Eurasia Quaternary stratigraphy and paleontology of the Southern Russia: connections between Europe, Africa and Asia, 21-26 June 2010, Rostov-on-Don, Russia, 2010.

Sotnikova, M. and Rook, L.: Dispersal of the Canini (Mammalia, Canidae: Caninae) across Eurasia during the late Miocene to early Pleistocene, Quaternary Int., 212, 86-97, 2010.

Stöcklin, J. and Eftekhar-Nezhad, J.: Explanatory Text of the Zanjan Quadrangle Map 1:250,000, Geological Survey of Iran, Report No. D4, 1-61, 1969.

Vialov, O. S.: Novüe iszkopaemüj szled ptieü v Miocene Predkarpatija [New Fossil footprint of a bird in the Miocene of Ciscarpathia], Doklady Akademii Nauk USSR, Earth Science Section, 135, 1310-1312, 1961.
Vialov, O. S.: Stratigrafiya Neogenovykh molass Predkarpatskovo progriba [Stratigraphy of the Neogene molasse of the PreCarpathian basin], Kiev, Naukova Dumka (Akademiya Nauk Ukrainskoy SSR Institut Geologii I Geokhimii Goryuchikh Iskopayemykh), 165 pp., 1965.

Vialov, O. S.: Sledy zhiznedeyatelnosti organizmov i ikh paleontologicheskoe znacheniye [Traces of living organisms and their paleontological significance], Kiev, Naukova Dumka (Akademiya Nauk Ukrainskoy SSR Institut Geologii I Geokhimii Goryuchikh Inskopayemykh), 5-219, 1966.

Vialov, O. S.: Pliocene bird tracks from Iran assigned to the genus Urmiornis, Paleontol. J., 23, 119-121, 1989.

Wang, X.: Phylogenetic systematics of the Hesperocyoninae (Carnivora, Canidae), B. Am. Mus. Nat. Hist., 221, 1-207, 1994.

Werdelin, L., Yamaguchi, N., Johnson, W. E., and O'Brien, S. J.: Phylogeny and evolution of cats (Felidae), in: New Views on Phylogeny, Form, and Function, edited by: Goswami, A. and Friscia, A., Cambridge University Press, Cambridge, 59-82, 2010. 